\title{
Physiological responses of Cnidoscolus quercifolius Pohl in semi-arid conditions
}

\author{
Fabio Rodrigues Ramos ${ }^{1}$ Antonio Lucineudo Oliveira Freire ${ }^{1 *}$ \\ ${ }^{1}$ Universidade Federal de Campina Grande, Unidade Acadêmica de Engenharia Florestal, Campus de Patos-PB
}

*Author for correspondence: lucineudofreire@gmail.com

Received: October 2017 / Accepted: February 2019 / Published: March 2019

\begin{abstract}
This study aimed to evaluate the physiological behavior of faveleira (Cnidoscolus quercifolius Pohl) plants grown in the field, in Caatinga, during wet and dry seasons. Adult plants were selected for evaluation in March and April (wet season) and May and June (dry season), during 2016. We evaluated the soil water content, water potential ( $\Psi \mathrm{w})$, osmotic potential $(\Psi \pi)$, relative water content (RWC), stomatal conductance $\left(g_{s}\right)$, transpiration rate $(E)$, photosynthetic rate $(A)$, intercellular $\mathrm{CO}_{2}$ concentration $(\mathrm{Ci})$, instantaneous water use efficiency $(A / E)$ and carboxylation efficiency $(\mathrm{A} / \mathrm{C} i)$. The reduction in water availability in the soil promoted a marked decrease in soil water potential, which was more affected than the relative water content. The opening of the stomata was affected by the decrease in soil moisture content, reducing the stomatal conductance, transpiration rate, photosynthesis rate, instantaneous water use efficiency and carboxylation efficiency. The photosynthesis was more affected than transpiration by the reduction in soil moisture content.
\end{abstract}

Keywords: Drought tolerance, Caatinga, Stomatal behavior

\section{Introduction}

Water availability is the main factor limiting plant growth and survival in semi-arid region of Brazil. The water deficit, combined with the intensive use of soil and disorderly exploitation of forest resources has led to an advanced soil degradation and desertification, because these factors cause changes in water balance patterns. Semi-arid regions are characterized by high temperatures and evaporation rates, with precipitation distributed usually between four and six months during the year. There is an annual variation in rainfall, with periodic droughts occurring in three to five years, with rainfall less than half the annual average, who is around $700 \mathrm{~mm}$ (Veloso et al. 2002; Sampaio 2010). The main vegetation component of the semi-arid is the Caatinga, that occurs only in Brazil, which covers $844,453 \mathrm{~km}^{2}$, corresponding to $9.92 \%$ of Brazilian territory (IBGE 2010).

Added to these climatic factors, the soils of the semi-arid region are generally shallow and stony, with low capacity of water retention, making adverse conditions for survival of the vegetal species (Alves et al. 2009). In spite of these factors, the Caatinga has a diversity of environments, with generally deciduous, xerophytic and sometimes prickly vegetation (Veloso et al. 2002). These plants, subject to these environmental conditions that few would support, developed different survival strategies, enabling them to compete for scarce water resources (Dombroski et al. 2011). Although it is the richest dry forest in biodiversity of the world (Holzman 2008), is the Brazilian ecosystem less studied and protected.

Water stress affects physiological process, like photosynthesis, transpiration, respiration, transport and accumulation of assimilates, exerting direct effects on plant growth and production (França et al. 2017; Costa et al. 2015;
Klippel et al. 2014; Scalon et al. (2011); Sampol et al. 2003). However, the way that plants respond to drought stress is complex, varies with the species and the age of the plant (Costa et al. 2015).

In recent years, more researches have been developed researches to understand the ecophysiological strategies of Caatinga plants under low water availability, especially during its initial development (Silva et al. 2004; Silva et al. 2004). However, there are few studies in the field, and these studies provide more consistent data than those performed in the laboratory, since there is a greater interaction between the environmental conditions and the physiological responses of the plants (Lacheveque et al. 2011; Ryan 2011).

One of the most representative plant species of the caatinga, the faveleira (Cnidoscolus quercifolius Pohl.) is an oleaginous, xerophilic, deciduous species (Maia 2004; Lorenzi 1998), with potential of use for several purposes, as in the recovery of degraded areas, biodiesel production, firewood and animal and human feeding, medicine, sawing, and energy (Maia 2004)

There is a scarce knowledge about the physiology of faveleira and data experimental approach would allow the expansion of knowledge about the specie of this biome aiming the development of strategies that allow a better exploration of its potentialities. Thus, this work was developed with the objective of evaluating the physiological behavior of plants of this species grown in the field during the rainy and early dry season.

\section{Material and Methods}

The study was undertaken in an area previously submitted to goat and bovine grazing during 30 years and since 2002 is in the process of recovery with native species of the caatinga (Mimosa tenuiflora Poiret, catingueira, and C. quercifolius), protected from grazing. This area is located in Nupearido Experimental Farm of the Federal University of Campina Grande (UFCG), Patos, Paraiba, Brazil ( $\left.7^{\circ} 04^{\prime} 54^{\prime \prime} \mathrm{S} ; 30^{\circ} 16^{\prime} 12^{\prime \prime} \mathrm{W}\right)$. According to Köppen's classification, the climate of the region is characterized as BS'h', semi-arid, with an annual average temperature above $25^{\circ} \mathrm{C}$ and an annual rainfall of less than $1,000 \mathrm{~mm} /$ year, with irregular rains (INSA 2012). The predominant type soil in the area is Litholic Neosoil.

The experiment was performed in a randomized blocks design (DBC), with subdivided plots $(2 \times 4)$, in which the main plot corresponded to the rainy and dry period and the subplots to the evaluated months (March, April, May, and June), with 4 replicates. Evaluations were performed on three leaves per replicate.

The evaluations were carried out on March 23 and April 22 (rainy season), May 23 and June 25 (dry season), 2016. The year 2016 was considered dry (Figure 1), which had been occurring since 2013. Due to the low rainfall registered and the finding of the beginning of foliar abscission in the faveleira plants, the months of May and June were considered as belonging to the dry season. 


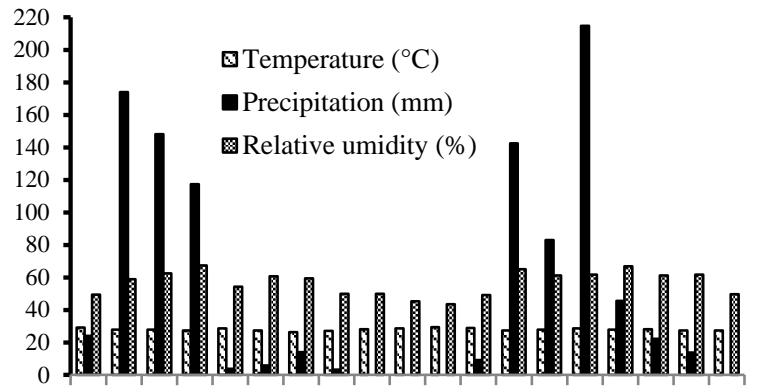

Jan Mar May Jul Sep Nov Jan Mar May Jul

Months (2015-2016)

Figure 1. Values of temperature, precipitation, and relative humidity in Patos, Paraiba, Brazil, during January 2015 and July 2016

Net $\mathrm{CO}_{2}$ assimilation rate $(A)$, stomatal conductance $\left(g_{s}\right)$, transpiration rate $(E)$, and internal $\mathrm{CO}_{2}$ concentration $(C i)$ were measured on fully-expanded leaves (three leaves per plant) with an Infra-Red Gas Analyser (IRGA LCpro+ ADC, Hoddesdon, UK). Measurements were performed between 9:00 and 11:00 am, using the atmospheric $\mathrm{CO}_{2}$ concentration and a photon flux density of $1200 \mu \mathrm{mol} \mathrm{m}{ }^{-2} \mathrm{~s}$ 1 . With the values of $A$ and $E$, the intrinsic water use efficiency (IWUE) and, with the data of $A$ and $C i$, the carboxylation efficiency $(\mathrm{A} / \mathrm{C} i)$ was calculated.

After the stomatal evaluations, the leaves were collected, wrapped in aluminum foil and placed in a styrofoam box containing ice, in order to reduce the loss of water to the maximum until they were taken to the laboratory for determination of leaf water potential $\left(\Psi_{\mathrm{w}}\right)$, which was performed using the pressure pump (Scholander et al. 1965), osmotic potential ( $\Psi$ s) (Bagatta et al. 2008) and relative water content (RWC). This was determined using leaf discs, calculated as $R W C(\%)=[(F W-D W) /(T W-D W)] X 100$ (Dias et al. 2014a), where $F W, D W$, and $T W$ correspond respectively to fresh weight, weight dry and turgid disc weight. For osmotic potential determination, the leaves were stored in a freezer $\left(-5^{\circ} \mathrm{C}\right)$ for two days. After thawing at room temperature, they were macerated in a mortar, and the extract was subjected to centrifugation $(3,000 \mathrm{rpm}$, for 5 minutes). Then, $2.5 \mathrm{~mL}$ of the supernatant was placed in tubes for determination of osmolarity in PZL 1000 Osmometer. The transformation of mosmol kg-1 to MPa was done using the equation $P O(M P a)=-c($ mosmol $/ \mathrm{kg}) x$ $2.58 \times 10^{-3}$, where $P O$ is osmotic potential and $c$ is the osmolarity of the sap (Bajji et al. 2001).

At the same time that the above evaluations were performed, soil samples (depth of 0-20 cm) were collected, in a number of four replications, to determine the soil water content by the gravimetric method, according to Embrapa methodology (1997).

All data were analyzed by One-Way Analysis of Variance (ANOVA), followed by Tukey's test for media value comparisons $(P \leq 0,05)$, using ASSISTAT software version 7.7 (Silva and Azevedo 2016).

\section{Results and Discussions} Water relations

The highest soil water content was observed in March (10.05\%), decreasing in the following months (Figure 2). The rainfall index between January and March 2016 was unsatisfactory, and together with the high temperatures (Figure 1), which favored the high evaporation rates, together with the soil characteristics, SWC can be considered low, possibly due to the soil characteristics
(Litholic Neosoil), which is stony and with low moisture retention. In the next months, with decrease rainfall, and the beginning of dry season, soil moisture reached $1.83 \%$ in June, representing $82 \%$ of reduction, while rainfall dropped from $214.7 \mathrm{~mm}$ (March) to $13.7 \mathrm{~mm}$ (June) or just $6.4 \%$ of the observed value. During the years 2015/2016 the El Niño phenomenon was strong, which has a close relation with the occurrence of drought in the Northeast region of Brazil, particularly in the semi-arid region (Costa 2016).
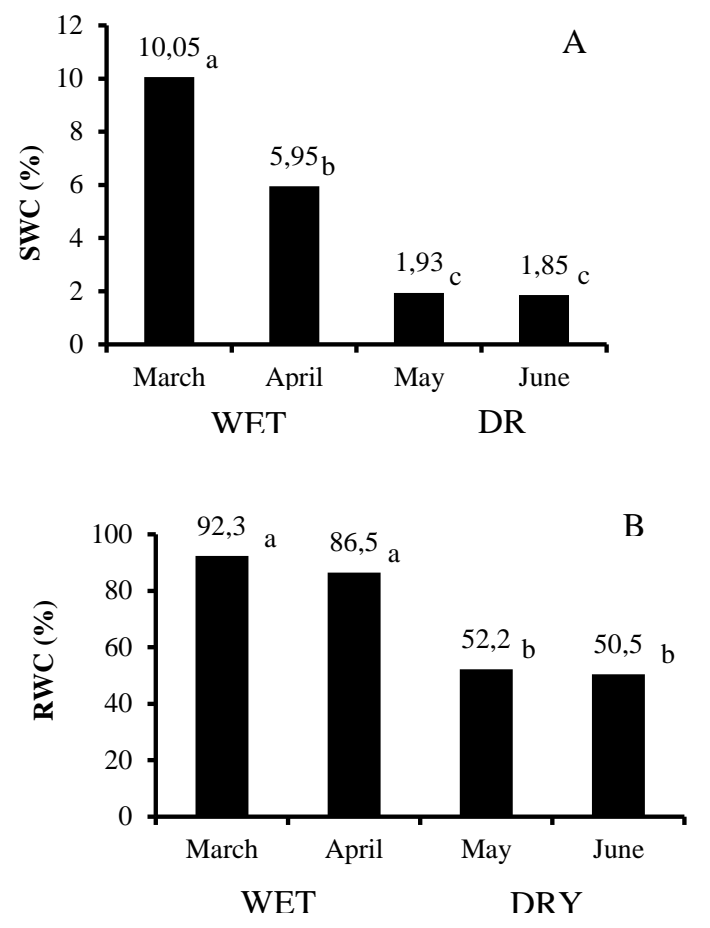

Figure 2. Soil water content (A) and leaves relative water content (B), in the two periods evaluated. Different letters indicated statistical differences between treatments $(\mathrm{P} \leq 0.05)$

Despite the decrease in soil moisture, from March to April, the RWC of leaves remained high, with no statistical difference between these evaluations (Figure 2B), possible due to the water absorption capacity, maintaining high $\Psi_{\mathrm{W}}$ (Figure 3). However, as a direct response to the rainfall reduction, and consequently soil moisture, in May and June, there was a strong reduction in tissue hydration, and the RWC reached an average value of $51 \%$, indicating the behavior of faveleira to water availability reduction. According to Pardo (2010), RWC values between $85 \%$ and $95 \%$ indicate a high state of hydration of the tissues, whereas the value of $50 \%$ is considered critical, and can cause tissue death. However, this author adds that some xerophilic species may reach this value and tissue death does not occur.

The direct relationship between the reduction in water availability for plants and the RWC has been verified in several studies, regardless of the methodology used, and the response varies with the studied plant species. Mendes et al. (2013) reported that the leaves water content in Cordia oncocalyx maintained in the Caatinga varied from $60 \%$ to $70 \%$ in the rainy season, falling to $50 \%$ in dry season. In Hevea brasiliensis, after 35 days without irrigation, Chen et al. (2010) observed a little reduction in the RWC, which was around $70 \%$. Valadares et al. (2014) reported values of $86 \%$ in RWC in hybrids of Eucalyptus grandis X E. urophylla, irrigated every four and six days. These values are higher than those obtained in this research, possibly due to the 
methodology used since the two studies reported were done in young plants growing in a pot and with controlled irrigation.

As a result of the changes reported in Figure 2, there was a decrease in osmotic potential $(\Psi \pi)$ and leaf water potential $(\Psi \mathrm{w})$ (Figure 3).
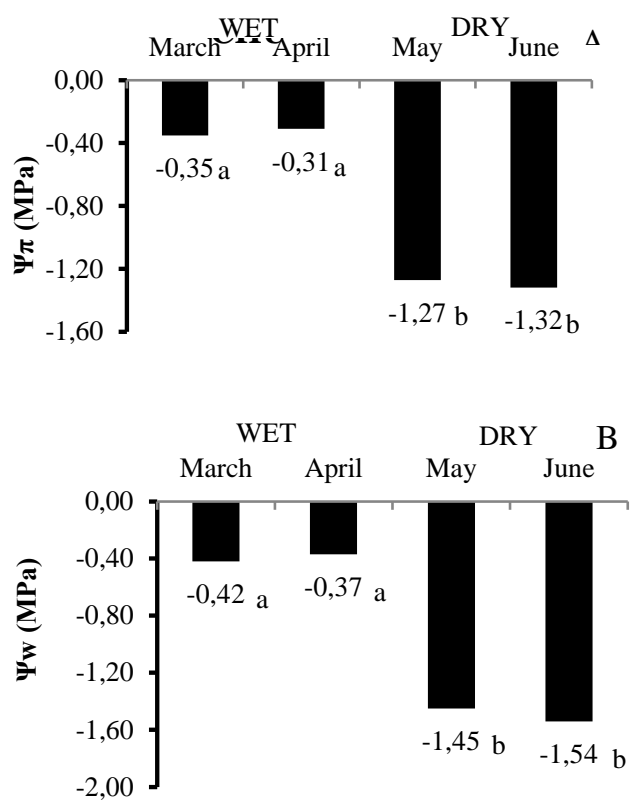

Figura 3. Leaf osmotic (A) and water potential (B) by faveleira, in the two periods evaluated. Different letters indicated statistical differences between treatments $(\mathrm{P} \leq 0.05)$

There was no significant differences in $\Psi_{\pi}$ and $\Psi_{\mathrm{w}}$ between the March and April, but comparing the wet and dry periods, it is verified that the $\Psi \pi$ reduced from -0.31 MPa (April) to $-1.27 \mathrm{MPa}$ (May) and $-1.32 \mathrm{MPa}$ (June) (Figure 3A), representing values about four times lower than those of April. The same was observed in $\Psi_{\mathrm{w}}$ (Figure 3B), revealing that reduction in water availability for faveleira was accompanied by a strong decrease in $\Psi \pi$ and $\Psi_{\mathrm{w}}$. However, in the above periods, the decrease in the RWC was only $40 \%$, although the value obtained was close to that considered critical (Pardo 2010). The results obtained of $\Psi_{\mathrm{W}}$ were higher than those found by Dombroski et al. (2011), in Mimosa caesalpiniifolia, Caesalpinia pyramidalis, Auxemma oncocalyx, Caesalpinia ferrea and Calliandra speciosa.

The highest decrease in $\Psi \pi$ and $\Psi \mathrm{w}$ in relation to RWC may have been due to a probable osmotic adjustment (Varone et al. 2012), which is a characteristic of drought tolerant plants (Villar-Salvador et al. 2004). Under water deficit conditions, maintenance of leaf turgor can be achieved by osmotic adjustment (Cordeiro et al. 2009), due to the accumulation of osmotically active compounds such as proline, glycine betaine, sucrose and soluble carbohydrates (Morghaieb et al. 2004).

\section{Gas exchange}

In March, due to higher rainfall (Figure 1), were observed higher values of stomatal conductance $\left(g_{s}\right)$, transpiration rate $(E)$, Net $\mathrm{CO}_{2}$ assimilation rate $(A)$, and lower internal $\mathrm{CO}_{2}$ concentrations $(\mathrm{Ci})$ (Figure 4).
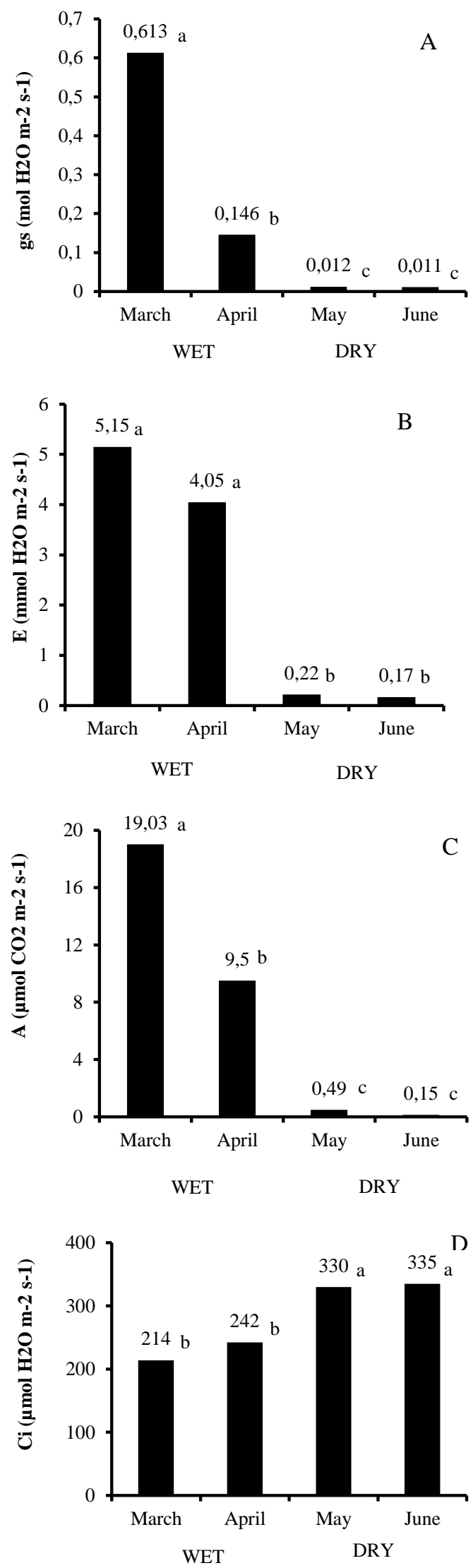

Figure 4. Stomatal conductance $\left(g_{s}\right)$, transpiration rate $(E), \mathrm{Net} \mathrm{CO}_{2}$ assimilation rate $(A)$ and internal $\mathrm{CO}_{2}$ concentration $(\mathrm{Ci})$ in faveleira, in the two periods evaluated. Different letters indicated statistical differences between treatments $(P \leq 0.05)$

With the soil water availability and SWC reductions occurred stomatal closure, reducing $g_{s}, E$ e $A$ (Figures 4A, 
4B, 4C). It was verified that, in June, the values of $A$ corresponded to only $0.8 \%$ of those obtained in March (99.2\% reduction). In $\mathrm{Ci}$ there was an increase of $56 \%$ (Figure 4D), comparing the rainy season with the dry season.

The SWC reduction (Figure 1A) and in $\Psi_{\mathrm{W}}$ (Figure 3B) induced a rapid stomatal closure before foliar abscission occurs. With the reduction in water availability, the ABA synthesis and its translocation to stomata, causing its closure (Taiz \& Zeiger 2013), minimizing water losses to the atmosphere and conserving the largest amount of water in the soil (Souza et al. al. 2014). This may be advantageous if the drought is prolonged (Sinclair et al. 2005; Martins et al. 2008), situation faced by the faveleira under field conditions. This is one of the first plant species of the Caatinga to initiate foliar abscission with the onset of the dry period, which may be an adaptive strategy to reduce leaf area and, consequently, water loss by transpiration. The abscission is caused by ethylene, accelerating leaf senescence and abscision (Abreu et al., 2015). It can be seen that the above-mentioned changes are strategies quickly employed by the species, aiming to minimize the loss of water. This way, allowing maintenance a good hydration of the tissues, so that the plant can cross the long period of drought and, after the resumption of rainfall, quickly start issuing new leaves.

Due reduction in $A$ and increased in $C i$, there was decrease in $\mathrm{A} / \mathrm{Ci}$ (Figure 4A). This means that although the $\mathrm{CO}_{2}$ flux (Figure 4D) has not been completely disrupted due to the reduction in $g_{s}$, photosynthesis has been compromised. This behavior suggests that biochemical limitations may justify the decrease of $A$ (Araújo et al. 2016), leading to reduction in biomass production and growth (Medrano et al. 2002).
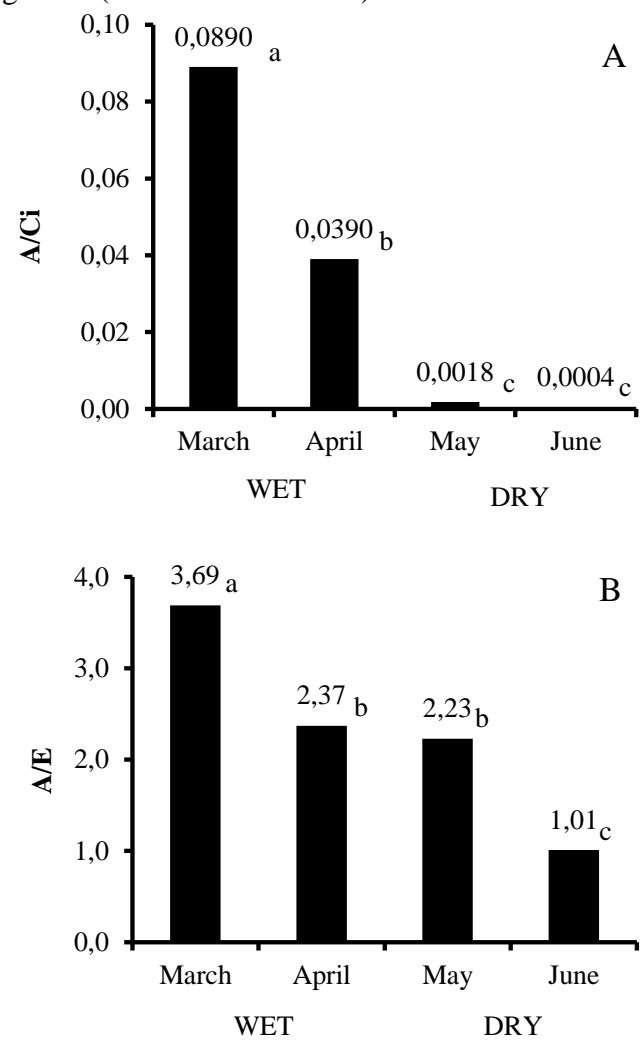

Figura 5. Photosynthetic efficiency $(A / C i)$ and intrinsic water use efficiency $(A / E)$ in faveleira, in the two periods evaluated. Different letters indicated statistical differences between treatments $(P \leq 0.05)$
As a result of the effects on the photosynthesis and transpiration rates, there was a decrease in $A / E$, as the soil water content (Figure 2A) and $\Psi_{\mathrm{w}}$ decreased (Figure 3D). The fact that there is a rapid decrease in leaf water potential and rapid stomatal closure with a reduction in soil moisture, before foliar abscission occurs, indicates the sensibility of the faveleira to the water deficit. According Jones (2004), water use efficiency (WUE) or transpiration efficiency is a conservative characteristic of species and cultivars, and increases with water stress as productivity is reduced. The conservative nature is due to genetic and environmental relationships coupling the plant to its environment (Glen 2010).

According to Taiz and Zeiger (2013), severe water stress causes a decrease in water content of mesophyll cells, affecting photosynthesis and water use efficiency. Rodríguez-Calcerrada et al. (2008) verified lower IWUE in Quercus pyrenaica during the dry season. In contrast, Dombroski et al. (2014) found an increase in this parameter in Handroanthus impetiginosus plants as the period without irrigation increased, whereas Gonçalves et al. (2009), in Carapa guianensis, did not find a significant difference between irrigated and non-irrigated plants. These results reinforce the information that the stomatal responses of the tree species to the reduction of soil water availability vary widely (Gonçalves et al. 2009).

The responses of the stomata seem to be more related to soil moisture content than to the leaf hydration status (Chaves et al. 2009). According to these authors, the stomata respond to chemical signals produced by the roots when the water deficit develops, like abscisic acid (ABA), at the same time that the leaf water status does not change.

The adverse effect of low soil water availability on gas exchange during the dry period has been widely reported. In this sense, Dombroski et al. (2011) reported a reduction in gs, E and A of Mimosa caesalpiniifolia, Caesalpinia pyramidalis, Auxemma oncocalyx, Caesalpinia ferrea, Calliandra speciosa and Tabebuia caraiba, as $\Psi \mathrm{w}$ decreased. Likewise, in $C$. oncocalyx these physiological parameters were strongly affected by low soil moisture content (Mendes et al. 2013). However, the transpiration was less influenced, similar to that verified in this study. Santos et al. (2013) reported in Jatropha curcas, during the dry period, which the higher moisture content of the subsoil forest provided a higher photosynthetic rate than that observed in the Caatinga semi-arid region. In six tree species, Campelo et al. (2015) verified a reduction in gas exchange and the photochemical efficiency of photosystem II in cultivated under irrigated and non-irrigated conditions, during the dry period.

The mechanisms of transpiration control constitute efficient processes to provide or maintain the cellular turgescence under dry conditions (Cordeiro et al. 2009). However, stomatal responses are not influenced only by water availability, since variations in temperature, light, relative humidity and wind speed may also affect them, evidencing the complexity of the stomatal mechanism (Angelocci et al. 2004).

Under controlled conditions, Valadares et al. (2014) reported that the reductions in transpiration and photosynthetic rates were due to stomatal closure, adding that stomatal conductance was more sensitive than those parameters. In Swietenia macrophylla, Cordeiro et al. (2009) verified a reduction in gs at the ratio $\psi \mathrm{w}$ decreasing and verified the close correlation between $g s, E$, the total hydraulic conductivity of the plants and the deficit of leaf-air vapor pressure. In plants of Tabebuia aurea, it was verified that the values of $E, g s$ and $A$ were null, four days after the suspension of irrigation, demonstrating that the species uses 
this mechanism to tolerate water deficit since recovery occurred after reirrigation (Oliveira et al. 2011).

The closure of the stomata constitutes one of the first responses of plants to the water deficit, minimizing water losses and, consequently, dehydration of cells and tissues (Albuquerque et al. 2013; Araújo et al. 2016). In addition to promoting the degradation of chlorophyll (Dichio et al. 2005), stomatal closure affects photosynthesis by reducing the availability of $\mathrm{CO}_{2}$ to ribulose-1,5-bisphosphate carboxylase/oxygenase (Rubisco) enzyme (Pinheiro and Chaves 2011; Dias et al. 2014b), affecting the activity or the capacity and speed of regeneration of the enzyme (Chaves et al. 2009). However, non-stomatal factors may also lead to a decrease in photosynthetic activity under conditions of low water availability (Boussadia et al. 2008). Occurs also losses of the photosynthetic system, as a consequence of the destructuring of the chloroplast thylakoid membranes (Dias and Brüggermann 2010), decrease in the transport of electrons in the PSII, in ATP synthesis, besides oxidative damage and/or photoinhibition (Galmés et al. 2007).

\section{Conclusions}

The faveleira plants maintain elevated water status and gas exchange during rainy season.

Occurs rapid stomatal closure with water availability reduction, reducing transpiration, photosynthesis, photosynthetic efficiency and intrinsic water use efficiency at beginning of the dry season.

\section{Acknowlegment}

To CAPES for the scholarship guarantee to the first author.

\section{References}

Abreu MC, Martins FB, Freitas CH, Pereira RAA, Melloni EGP (2015) Valores limítrofes para transpiração, desenvolvimento e crescimento de Corymbia citridora (Hook.) K.D. Hill \& L.A.S. Johson em resposta à deficiência hídrico no solo. Revista Árvore 39(5):841852. http://dx.doi.org/10.1590/010067622015000500007

Albuquerque MPF, Moraes FKC, Santos RIN, Castro GLS, Ramos EML, Pinheiro HA (2013) Ecofisiologia de plantas jovens de mogno-africano submetidas a déficit hídrico e reidratação. Pesquisa Agropecuária Brasileira 48(1):9-16. doi: 10.1590/S0100204X2013000100002

Alves JJA, Araújo MA, Nascimento SS (2009) Degradação da Caatinga: uma investigação ecogeográfica. Revista Caatinga 22(3):126-135.

Angelocci LR, Marin FR, Oliveira RF, Rigui EZ (2004) Transpiration, leaf diffusive conductance, and atmospheric water demand relationship in an irrigated acid lime orchard. Brazilian Journal Plant Physiology 16(1):53-67. http://dx.doi.org/10.1590/S167704202004000100008

Araújo SMS (2011) A região semiárida do Nordeste do Brasil: questões ambientais e possibilidades de uso sustentável dos recursos. Revista Rios Eletrônica 5(5):89-98.

Araújo M, Santos C. Costa M, Moutinho-Pereira J, Correia C, Dias MC (2016) Plasticity of young Moringa oleifera plants to face water deficit and UVB radiation challenges. Journal of Photochemistry \& Photobiology, B: Biology 162:278-285. http://dw.doi.org/10.1016/j.jphotobiol.2016.06.048
Bagatta M, Pacifico D, Mandolino G (2008) Evaluation of the osmotic adjustment response within the genus Beta. Journal of Sugar Beet Research 45(3/4):119-133.

Bajji M, Lutts S, Kinet JM (2011) Water deficit effects on solute contribution to osmotic adjustment as a function of leaf ageing in three durum wheat (Triticum durum Desf.) cultivars performing differently in arid conditions. Plant Science 160:669-681. https://doi.org/10.1016/S0168-9452(00)00443-X

Bota J, Medrano H, Flexas J (2004) Is photosynthesis limited by decreased Rubisco activity and RuBP content under progressive water stress? New Phytologist 162:671-681. DOI: 10.1111/j.14698137.2004.01056.x

Boussadia O, Mariem FB, Mechri B, Boussetta W, Braham M, El Hadj S B (2008) Response to drought of two olive tree cultivars (cv Koroneki and Meski). Scientia Horticulturae 116:388-393. https://doi.org/10.1016/j.scienta.2008.02.016

Cabral EL, Barbosa DCA, Simabukuro EA (2004) Crescimento de plantas jovens de Tabebuia aurea (Manso) Benth. \& Hook. f. ex S. Moore submetidas a estresse hídrico. Acta Botanica Brasilica 18(2):241251.

Campelo DH, Lacerda CF, Sousa JA, Correia D, Bezerra AME, Araújo JD, Neves ALR (2015) Trocas gasosas e eficiência do fotossistema II em plantas adultas de seis espécies florestais em função do suprimento de água no solo. Revista Árvore 39(5):973-983. http://dx.doi.org/10.1590/0100-67622015000500020

Carvalho CJR (2005) Responses of Schizolobium amazonicum [S. parahyba var. Amazonicum] and Schizolobium parahyba [Schizolobium parahybum] plants to water stress. Revista Árvore 29(6):907-914. http://dx.doi.org/10.1590/S0100-67622005000600009

Chaves MM, Flexas J, Pinheiro C (2009) Photosynthesis under drought and salt stress: regulation mechanisms from whole plant to cell. Annals of Botany 103:551560. https://doi.org/10.1093/aob/mcn125

Chen JW, Zhang Q, Li XS, Cao KF (2010) Gas exchange and hydraulics in seeedlings of Hevea brasiliensis during water stress and recovery. Tree Physiology 30:876-885. https://doi.org/10.1093/treephys/tpq043

Cordeiro YEM, Pinheiro HA, Santos Filho BG, Corrêa SS, Silva JRR, Dias-Filho MB (2009) Physiological and morphological responses of Young mahogany (Swetenia macrophylla King) plants to drought. Forest Ecology and Management 258:1449-1455. https://doi.org/10.1016/j.foreco.2009.06.054

Costa JA (2016) O fenômeno El Niño e as secas no Nordeste do Brasil. Educação, Tecnologia e CulturaE.T.C. n.2.https://publicações.ifba.edu.br/index.php/ etc/article/view/55.

Dias MC, Brüggermann W (2010) Limitations of photosynthesis in Phaseolus vulgaris under drought stress: gas exchange, chlorophyll fluorescence and Calvin cicle enzyms. Photosynthetica 48:96-102.

Dias MC, Oliveira H, Costa A, Santos C (2014a) Improving elms performance under drought stress: the pretreatment with abscisic acid. Environment Experimental of Botany 100:64-73. https://doi.org/10.1016/j.envexpbot.2013.12.013 
Dias MC, Azevedo C, Costa M, Pinto G, Santos C (2014b) Melia azedarach plants show tolrance properties to water shortage treatment: na ecophysiological study. Plant Physiology and Biochemistry 25:123-127. http://dx.doi.org/10.16/j.plaphy.2013.12.013

Dichio B, Xiloyannia C, Sofo A, Montanaro G (2005) Osmotic regulation in leaves and roots of olive during a water deficit and recovery. Tree Physiology 26:179185. https://doi.org/10.1093/treephys/26.2.179

Dombroski JLD, Praxedes SC, Freitas RMO, Pontes FM (2011) Water relations of Caatinga trees in the dry season. South African Journal of Botany 77:430-434. https://doi.org/10.1016/j.sajb.2010.11.001

Dombroski JLD, Freitas RMO, Tomczak VE, Pinto JRS, Farias RM (2014) Ecophysiology of water stressed Handroanthus impetiginosus (Mart. ex DC) Mattos seedlings. Scientia Forestalis 42(101):155-163.

Embrapa. Empresa Brasileira de Pesquisa Agropecuária (1997) Manual de métodos de análise de solo. Rio de Janeiro: Ministério da Agricultura.

Flexas J, Bota J, Loreto F, Cornic G, Sharkey TD (2004) Diffusive and metabolic limitations to photosynthesis under drought and salinity in C3 plants. Plant Biology 6:269-279.

Flexas J, Medrano H (2002) Drought-inhibition of photosynthesis in $\mathrm{C} 3$ plants: stomatal and non-stomatal limitations revisited. Annals of Botany 89:183-189. https://doi.org/10.1093/aob/mcf027

Galmés J, Medrano H, Flexas J (2007) Photosynthetic limitations in response to water stress and recovery in Mediterranean plants with different growth forms. New Phytologist 175:81-93. doi: 10.1111/j.14698137.2007.02087.x

Glenn DM (2010) Canopy gas exchange and water use efficiency of 'empire' apple in response to particle film, irrigation, and microclimatic factors. Journal of the American Society for Horticultural Science 135(1):25-32.

Gonçalves JFC, Silva CEM, Gato D (2009) Fotossíntese e potencial hídrico foliar de plantas jovens de andiroba submetidas à deficiência hídrica e à reidratação. Pesquisa Agropecuária Brasileira 44(1):8-14.

IBGE. Instituto Brasileiro de Geografia e Estatística (2011) Censo Demográfico 2010. Rio de Janeiro: IBGE.

INSA. Instituto Nacional do Semiárido (2012) Disponível em <http://www.insa.gov.br >

Instituto Nacional de Meteorologia (2016) Disponível em < http://www.inmet.gov.br >

Jones $H$ (2004) What is water use efficiency? In: Bacon MA (ed.). Water use efficiency in plant biology. CRC Press, Boca Raton, FL. p.27-40.

Koslowski TT, Pallardy SG (1997) Growth control in woody plants. San Diego: Academic Press.

Larcheveque M, Maurel M, Desrochers A, Larocque GR (2011) How does drought tolerance compare between two improved hybrids of balsam poplar and an unimproved native species? Tree Physiology 31:240249. https://doi.org/10.1093/treephys/tpr011
Lorenzi H (1998) Árvores brasileiras: manual de identificação e cultivo de plantas arbóreas nativas do Brasil. Vol 1. Nova Odessa: Instituto Plantarum de Estudos da Flora. 373p.

Maia GN (2014) Caatinga: árvores e arbustos e suas utilidades. São Paulo: D\&Z. 413p.

Martins FB, Streck NA, Silva JC, Morais WW, Susin F, Navroski MC, Vivian MA (2008) Deficiência hídrica no solo e seu efeito sobre transpiração, crescimento e desenvolvimento de mudas de duas espécies de eucalipto. Revista Brasileira de Ciência do Solo 32(3):1297-1306.

Medrano H, Escalona JM, Bota J, Gulias J, Flexas J (2002). Regulation of photosynthesis of C3 plants in response to progressive drought. Stomatal conductance as a reference parameter. Annals of Botany, 89: 895905.

Mendes MMS, Lacerda CF, Fernandes FEP, Cavalcante ACR, Oliveira TS (2013) Ecophysiology of deciduos plants grown at different densities in the semiarid region of Brazil. Theoretical and Experimental Plant Physiology 25(2):94-105.

http://dx.doi.org/10.1590/S2197-00252013000200002

Moghaieb REA, Saneoka H, Fujita K (2004) Effect of salinity on osmotic adjustment, glycinebetaine accumulation and betaine aldehyde dehydrogenase gene expression in two halophytic plants, Salicornia europaea and Sueda maritime. Plant Science 166:1345-1349.

https://doi.org/10.1016/j.plantsci.2004.01.016

Oliveira AKM, Gualtieri SCJ, Bocchese RA (2011) Gas Exchange of potted Tabebuia aurea plants under hydric stress. Acta Scientiarum. Agronomy 33(4):641647. http://dx.doi.org/10.4025/actasciagron.v33i4.11254

Pardo JM (2010) Biotechnology of water and salinity stress tolerance. Current Opinion in Biotechnology 21:185-196 https://doi.org/10.1016/j.copbio.2010.02.005

Parry MAJ, Andralojc PJ, Khan S, Lea PJ, Keys AJ (2002) Rubisco activity: effects of drought stress. Annals of Botany 89:833-839. https://doi.org/10.1093/aob/mcf103

Pinheiro C, Chaves MM (2011) Photosynthesis and drought: can we make metabolic connections from available data? Journal of Experimental Botany 62:869-882. https://doi.org/10.1093/jxb/erq340

Rodríguez-Calcerrada J, Pardos JA, Gil L, Aranda I (2008) Ability to avoid water stress in seedlings of two aok species is lower in a dense forest understory than in a medium canopy gap. Forest Ecology and Management 255:421-430. https://doi.org/10.1016/j.foreco.2007.09.009

Ryan MG (2011) Tree responses to drought. Tree Physiology 31:237-239. https://doi.org/10.1093/treephys/tpr022

Sampol B, Bota, J, Riera, D, Medrano H, Flexas J (2003) Analysis of the virus-induced inhibition of photosynthesis in malmsey grapevines. New Phytologist 160:403-412. doi: 10.1046/j.14698137.2003.00882.x 
Santos CM, Veríssimo V, Wanderley-Filho HCL, Ferreira VM, Cavalcante PGS, Rolim EV, Endres L (2013) Seasonal variations of photosynthesis, gas exchange, quantum efficiency of photosystem II and biochemical responses of Jatropha curcas L. in semi-humid and semi-arid areas subject to water stress. Industrial Crops and Products 41:203-213.

https://doi.org/10.1016/j.indcrop.2012.04.003

Scholander PF, Bradstreet ED, Hemmingsen EA, Hammel HT (1965) Sap pressure in vascular plants. Negative hydrostatic pressure can be measured in plants. Science 148:339-346.

Silva FAZ, Azevedo CAV (2016) The Assistat Software Version 7.7 and its use in the analysis of experimental data. African Journal of Agriculture Research 11:3733-3740. doi: 10.5897/AJAR2016.11522

Silva EC, Nogueira RJMC (2003) Crescimento de quatro espécies lenhosas cultivadas sob estresse hídrico em casa-de-vegetação. Revista Ceres 50(288):203-217.

Silva EC, Nogueira RJMC, Azevedo Neto AD, Brito JZ, Cabral EL (2004) Aspectos ecofisiológicos de dez espécies em uma área de caatinga no município de Cabaceiras, Paraíba, Brasil. Iheringia, Série Botânica 59(2):201-205.

Sinclair TR, Holbrook NM, Zwieniecki MA (2005) Daily transpiration rates of woody species on drying soil. Tree Physiology 25(11):1469-1472.

Souza AT, Streck NA, Heldwein AB, Bisognin DA, Winck JEM, Rocha TSM, Zanon AJ (2014) Transpiration and leaf growth of potato clones in response to soil water deficit. Scientia Agrícola 71(2):96-104.

Sircelj H, Tauszb M, Grill D, Batic F (2007) Detecting different levels of drought stress in apple trees (Malus domestica Borkh.) with selected biochemical and physiological parameters. Scientia Horticulturae 113:362-369.

https://doi.org/10.1016/j.scienta.2007.04.012

Taiz L, Zeiger E (2013) Fisiologia Vegetal. Porto Alegre: Artmed. 918p.

Valadares J, Paula NF, Paula RC (2014) Physiological changes in eucalyptus hybrids under different irrigation regimes. Revista Ciência Agronômica 45(4):805-814. http://dx.doi.org/10.1590/S180666902014000400019

Varone L, Ribas-Calbo M, Cardona C, Gallé A, Medrano H, Gratani L, Flexas J (2012) Stomatal and nonstomatal limitations to photosynthesis in seeedlings and saplings of Mediterranean species pre-conditioned and aged in nurseries: different response to water stress. Environmental and Experimental Botany 75:235-247. https://doi.org/10.1016/j.envexpbot.2011.07.007

Velloso AL, Sampaio EVSB, Pareyn FGC (2002) Ecorregiões propostas para o bioma Caatinga. Recife: Associação Plantas do Nordeste; Instituto de Conservação Ambiental The Nature Conservancy do Brasil. 76p.

Villar-Salvador P, Planelles R, Enriquéz E, PeñuelasRubira J (2004) Nursery cultivation regimes, plant functional atributes, and field performance relatioshinps in the Mediterranean oak Quercus ilex L.
Forest Ecology and Management 196:257-266. https://doi.org/10.1016/j.foreco.2004.02.061 